\title{
ロシア経済の回復，その原因と今後の展望
}

\author{
上垣 彰 \\ (西南学院大学経済学部教授)
}

\section{Economic Recovery in Russia: Its Causes and Prospects}

\author{
UEGAKI, Akira \\ Seinan Gakuin University
}

\begin{abstract}
The economic recovery of Russia after the financial crisis in August 1998 has been driven by a large amount of "net export". The "net export" was produced by low exchange rate of ruble and high price of oil. Using rough estimates of the future trend of the exchange rate and oil price, we can conclude that the Russian economic boom will not suffer a serious setback in the near future. In the longer term, however, Russia will face political and economic difficulties if Russians cannot restructure the oil-gas monoculture, which has been existed at the core of the economic recovery until now.
\end{abstract}

\section{1 ロシア経済の危機と回復}

\section{（1）短期的経済停滞}

1998 年 8 月の金融危機はロシア経済に多大な影響を与えたようにみえる。1995 年の水準を 100 として 1998 年 8 月に 107.4 にまで上昇していた財・サーヴィスの月間実質消費は 9 月以降

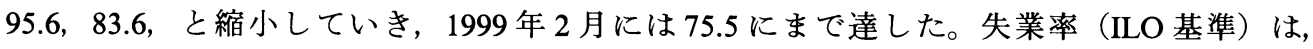
1998 年 8 月まで (月末水準) $11.3 \%$ から $11.7 \%$ の間を推移していたのが, 1998 年 10 月以降 $12 \%$ を越え，1999年 2 月には $14.1 \%$ まで上昇した。

しかし，この経済停滞は長くは続かなかった。実質消費は，1999年後半には徐々に回復し 始め 1999 年 12 月には 1995 年の水準に戻った。失業率も1999 年 2 月以降上昇する気配をみせ ず，1999 年第 4 四半期には 12.9\%（11 月末のデータ）といら水準に留まった。結局，1999年 の実質 GDPは，1998 年と比較して，むしろ増加したのである(1)。

このように経済停渔が短期間で終了した原因は，危機の影響を正面から受けたロシアの銀行 がロシア経済の実態とかかわりのない業務展開をしていたこと，したがって，銀行が危機状態

Keywords: net export, exchange rate, oil price, monoculture

(1) ここまでの統計データは RET (Monthly), 11 Oct. 2000 各所による。ただし，1999 年第 4 四半期の失業 率は RET, Vol. 11 (2002), No. 4, p. 90 による。 
に陥っても実体経済はそのことに影響を受けなかったことにある。

塩原（2004）は，これを「金融深化」度の低さから説明した。塩原は市中流通現金通貨及び 譲渡性預金，定期性預金，貯蓄性預金，外貨預金の合計（ほぼM2 と考えてょい）が GDPに 占める割合（GDPはフロー量であり，通貨量はストック量であるので当該年の GDPを当該 年末時点の通貨量と比較）を示した IFS の資料を使って，ロシアのその比率（例壳ば 1997 年 に 18.4\%）が，チェコ共和国（同年 69.9\%）やハンガリー（同年 46.5\%）に遠く及ばないはも ちろんのこと, ブルガリア（同年 33.5\%）やルーマニア（同年 24.6\%）の水準に達していない ことを明らかにし（p. 192），「銀行に集まった預金が貸し出しを通じて経済活動の拡大につな がるといら資金循環がロシアのような国ではうまく機能していない」とした（p. 191）。また， 塩原は，「民間部門に対する銀行の請求権の対 GDP 比」といら指標においてもロシアが非常 に低位であるという世界銀行の資料も引用している（p. 199）(2)。その結果，「金融深化の度合 いが相対的に低かったため,（1998 年 8 月危機の）経済混乱は予想外に軽微であった」と主張 している（p. 172 注 38）。この主張は泀ぼ頡けるものである(3)。銀行恐慌は，破綻に瀕した銀 行が，一般企業に対して追加融資を抑制し，または貸付資金の返済を強制する結果，一般企業 が支払不能に陥り，それが他企業への支払不能へと連鎖することによって生じる。一般企業の 破綻は, 生産の減少, 雇用の減少, 消費の減少へとつながっていく。もし, 銀行が一般企業に 対する貸付債権をそれほど持っていなければ，この連鎖は発生しない。

ではなぜ，短期間ではあっても，マクロ指標が悪化したのだろらか。筆者は，その原因は， 第 1 に，石油価格の下落が 8 月危機以後も短期間続いたことにあるとみている。ロシア連邦の 1997 年の原油輸出価格（1トン当たり）は 1996 年と比較して $10 \%$ 強の低下をみせたが, 1998 年にはこの原油価格低下の勢いが加速し，1998 年 11 月の実績（原油輸出額／原油輸出量）で は 1 トン当たり 65.1 ドルとなった。これは前年 11 月の実績と比較すると 45\% の低下であっ た（SEP, 9 Feb. 1999, Section 10.1.3）。そのため，為替が下落したあとも，すぐには，輸出額は 回復しなかった。また，第 2 に，急激な為替の下落は，「担ぎ屋」輸入を激減させたが，その 欠落を埋める国内軽工業の復活には若干の時間が必要だった。1995 年の生産水準を 100 とし て「繊維・履物」生産は 1998 年第 4 四半期に 59 に落ち込んだが，その指数は，1999年第 1 四半期に 68, 第 2 四半期に 79, 第 3 四半期に 85 となり，第 4 四半期になってもまだ 89 とい ら水準だった。しかし，回復が遅れていたのは，軽工業分野ばかりではない。「建設資材」生 産も1995 年水準を 100 として，1998 年第 4 四半期には 77 まで落ち込んだが，その水準は容 易に回復せず，1999年第 4 四半期に 83 だった。これは投資の回復の遅れと関連している。 1995 年の水準を 100 とした「粗固定資本形成」の水準は, 1998 年第 4 四半期に 63 まで落ち込 み, その後 1999 年第 1 四半期に 72, 第 2 四半期に 70, 第 3 四半期に 72, 第 4 四半期に 75 と 推移した。

\section{（2）急速な経斉回復}

しかし，これらの条件が解消していくにつれて，ロシア経済は回復していった。特に，「機

(2)この点に関しては, Lisin, 2004, p. 26 に詳しい。

(3) ただし，ロシアのような混乱期にある経済に，いかに「金融深化」のような概念を当てはめ，それを 他国と比較するかといら課題にはな険討すべき問題が残されている。たとえば，朽木他（2004, pp. 231-232）を参照せよ。 
械」,「化学」の分野は, 1999 年の第 1 ないし第 2 四半期に 1995 年水準を回復すると, 急速に 生産を伸ばし，1999 年第 4 四半期には 1995 年水準をともに $10 \%$ 以上上回る実績を残した ${ }^{(4)}$ 。

2000 年以降の経済回復はさらに目を見張らせるものがある。すでに言及したように 1999 年

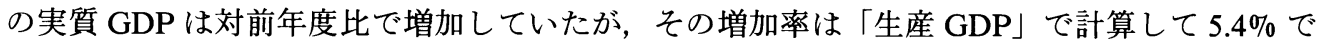
あった。ところが，2000 年には生産 GDP の対前年比増加率は $9.0 \%$ もの高率となった。2001 年以降も成長は続き，2001 年は 5.0\%，2002 年には $4.7 \%$ と成長し，2003 年には再び $7.3 \%$ の 高成長となった(5)。

失業率は 2000 年初め以降継続的に低下した。1999 年第 4 四半期に $12.9 \%$ だった失業率は, 2000 年 2 月末には $12.1 \% ， 2000$ 年 11 月末には $9.8 \%$ となり，さらに，2001 年 11 月末に $8.9 \%$, 2002 年 5 月末に $7.7 \%$ となった ${ }^{(6)}$ 。

財政も劇的に改善した。1999年度の統合予算(7)ではすでに財政赤字はGDPの $1 \%$ という水 準になっていたが（RET Monthly, April 2002），2000 年，2001 年には逆にそれぞれ 2.9\%の黒 字となった。内外のデット・サーヴィス分を支出から差し引いて計算した「プラィマリー・バ ランス」は, 2000 年, 2001 年とも対 GDP 比 5.6\% の黒字といら高水準となった（RET, Vol. 11, No. 4, p. 98)。ロシア経済の宿疴ともみられた財政赤字がこのように劇的に改善されていく とは誰が予想したであろうか。IMF の強い圧力によって未納税の徵収が進んだこと（政府の 徵税努力については Bukaev, 2000)，そしてなにより，2000年以降の輸出急払大によって大口 納税者の利益が拡大したことがこのような事態を招いたのである。

投資も払大している。新建築・設備への実質支出額（季節調整済み数值）は, 1997 年の水 準を 100 として，1998 年 12 月には 82 にまで低下していたが，その後徐々に上昇し，1999年 9月に 100 を越光，2000年 8 月には114.7にまでなっている (RET Monthly, Oct. 2000付属統計)。 国民所得統計（National Account）の「粗固定資本形成」のデータをみると，1995年水準を 100 として 1998 年第 4 四半期には 68.6 にまで下落していた（季節調整のらえ年間値に換算） のが，2000 年第 1 四半期には 77.6, 2000 年第 4 四半期は 82.9, そして 2001 年第 4 四半期には 96.7 にまで回復した（RET, Vol. 11, No. 4, p. 82; 2000 年基準の指数を筆者が再計算）。ゴスコム スタット, 経済分析センター, ロシア経済バロメータの 3 者が計算した前年比「固定資本投資 増加率」をみると，2000年から 2003 年をで，それぞれ $17.4 \% ， 8.7 \% ， 2.6 \% ， 12.2 \%$ とこれ も大きく成長している（The World Bank, 2004，付属統計表)。

ここで強調すべきは，いずれの指標でみても，2000年に急成長を遂げたロシア経済が, 2001 年, 2002 年と成長を鈍化させるかにみえたのに, 2003 年にまた急成長していることであ る。

(4) 以上の工業生産・投資データは, RET, Vol. 10 (2001), No. 3, pp. 78-79（ただし，2000年を100とした 季節調整済みデータを，1995 年水準を 100 として筆者が再計算した）。

(5) 成長率の数字は, 2001 年までの「生産 GDP」成長率に関しては, RET, Vol. 11 (2002), No. 4, p. 85 か ら筆者が計算。2002 年, 2003 年に関しては World Bank, Russian Economic Report, February 2004 付属 統計より引用。世界銀行レポートがあげている 2000 年, 2001 年の数字はそれぞれ 10.0\%, 5.1\%。

(6) RET, Vol. 11 (2002), No. 4, p. 90 失業率の定義は ILO 基準。

(7) 連邦予算と地方予算とを合計したもの。 
表 1 支出 GDP 構造 $(\%)^{1}$

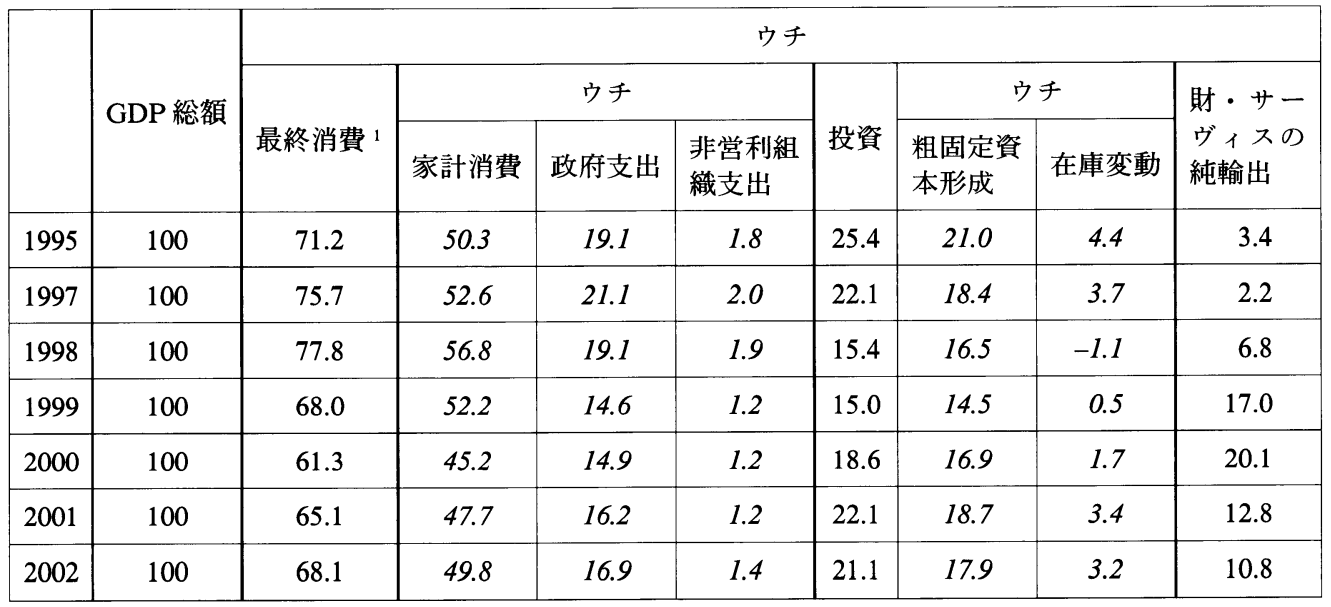

注） ${ }^{1}=$ 各比率は，時価市場価格（石油・ガスの輸出価格上昇が純輸出の比重増に貢献しているのだから， 「時価」であることに意味がある)での統計から計算されている。

$2=$ 各項目の用語はロシア語直訳ではなく，通常のマクロ経済学の用語に翻訳した。

出典) $R T S, 2003$ (インターネット版) 12.6 表

\section{2 経済回復の原因}

\section{（1）支出 GDP の構成要素}

何がこのような好調な経済を生み出したのだろらか。この問題をまずマクロ経済の基本構造 から考えてみよう。表 1は, ロシア連邦国家統計局が計算した支出 GDP の構造を示している。 ここから，1999年以降のロシア連邦の経済成長をもたらしたものが何であるか, 一目瞭然で ある。「財・サーヴィスの純輸出」(8) の増加が成長を牽引したのである。この「純輸出」の増 加は, 輸入の減少と石油・ガスの輸出額増によるものである。1998 年からすでに「純輸出」 の貢献が若干高まっているのは, 1998 年 8 月 17 日以降の輸入減少がいかに激しかったかを物 語っている。他方， 2001 年以降「純輸出」の貢献が低下したのは，「家計消費」,「政府支出」, 「投資」がそれぞれ若干ずつその貢献度を高めたからであるが，それらが石油・ガスの輸出の 増加によってきっかけを与えられえたものであることは明らかである。世界銀行の報告書は 2003 年の成長に関して次のようにいっている。「天然資源分野以外の部門での成長はロシアの 国内経済の自律的な回復の結果というよりも，石油・ガスの高価格が乗数的に経済におよぼし た 2 次的効果の結果である」（The World Bank, 2004, p. 4）（石油・ガス価格については次項で 詳しく説明する)。例えば，工業生産の内訳をみると，「機械製造」が 2000 年以来高い成長を 達成したことがわかるが，少なくとも2003 年に関してはこの「機械製造」には前年比で $35.8 \%$ も成長した石油運搬用貨車の製造が含まれている。同報告書によれば「歴史的にロシア が石油価格の上昇なしに 5.5\% 以上の成長をしたことはない」(The World Bank, 2004, pp. 4-5)。

「家計消費」および「粗固定資本形成」の貢献度の動きも興味深い。両者は，1999～2000

(8)「財・サーヴィスの純輸出」=「財・サーヴィスの輸出」ー「財・サーヴィスの輸入」 


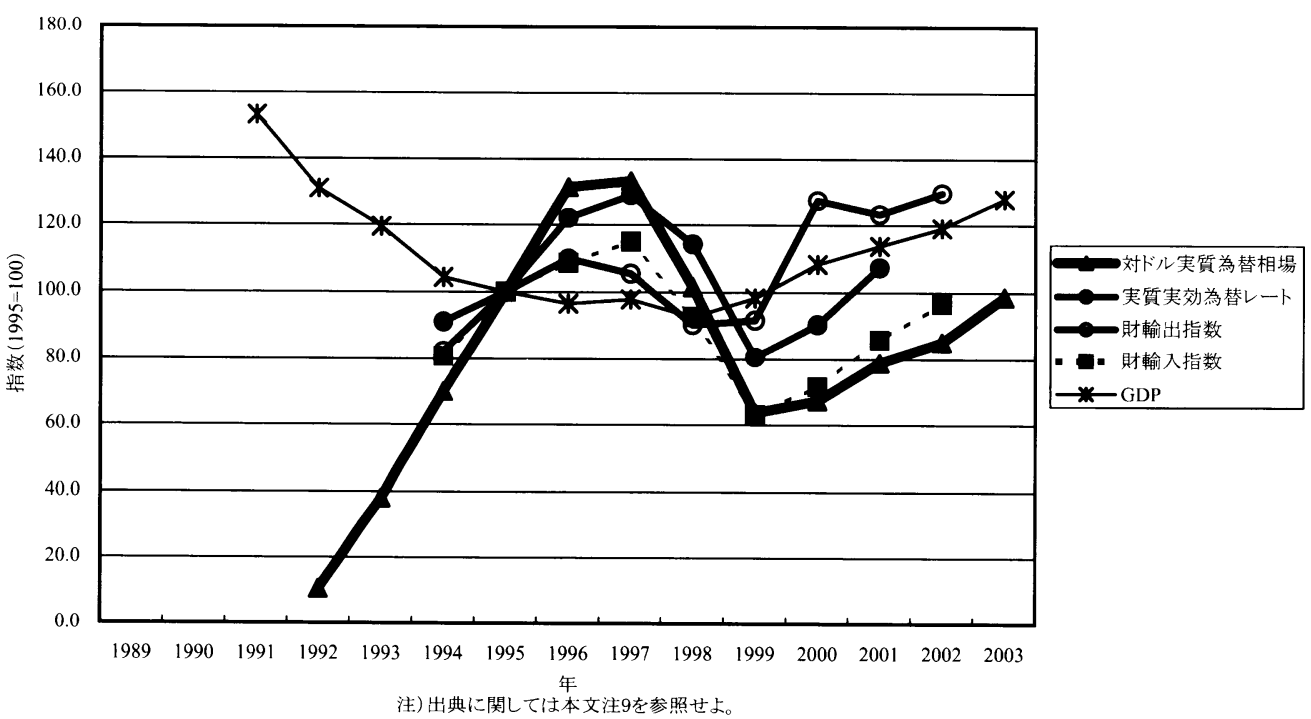

図 1 ロシアの為替相場・輸出・輸入・GDP

年まで下落を続け，2000～2001年になって初めて上昇に転換しているからである。すなわち， 「純輸出」の動きとはタイムラグが存在するのである。危機勃発後の消費者, 企業家に対する 心理的影響が作用していると推論できる。

「政府支出」の貢献度については，それが，危機後に低下し，その後若干盛り返しているが， 危機前の水準には至っていない。少なくとも，危機をケインズ政策で打開しょうとするロシア 政府の意図をここから汲み取ることはできない。

\section{（2）実質為替相場——対ドル実質」と「実罂実効」}

ロシア連邦で危機後なぜ「純輸出」の GDPへの貢献度が高まったか，その理由はまず，為 替相場の下落に求められねばならない。ルーブルの対ドル名目相場は 1998 年 7 月には平均 1 ドル $=6.272$ だったのが， 8 月 17 日以後 1 ドル $=20$ ルーブル以下に一挙に下落し，そのまま の水準で翌年まで推移した。1999 年の年間平均対ドル相場は 1998 年のそれの 2.5 分の 1 に下 落したのである（IFS 各所）。為替がこれほど急速に下落すれば，輸出に有利に，輸入に不利 に働くのは当然であり，「純輸出」が急拡大するのも当然といえよう。こういら意味では，コ リドール制の崩壊，すなわち外国人アドヴァイザーたちの惩涌した政策の失敗がロシア経済の 急回復を可能にしたのである。しかし，この問題はさらに詳細な検討が必要である。

図 1 はロシア連邦に関して，筆者が計算した「対ドル実質為替相場」，IMFによる「実質実 効為替相場」, ECE の報告書からとった「財輸出額」・「財輸入額」・「GDP」の諸データを，そ れぞれ，1995 年水準を 100 として指数化し，グラフにしたものである(9)。ここで，輸出入額

(9) 以下のよらな資料に基づいて筆者が指数化し作成した。「対ドル実質為替相場」：UN, ECE (2004), No. 1, p. 203 の「対ドル名目為替相場」(年間平均值) と同 p. 196 の「消費者物価指数」のデータをもと に筆者が計算。「実質実効為替相場」:IFS, 2002, Yearbook, country table [Russia]（このデータの定義は 同 p..x 抢よび p. 1081 を参照せよ)。「輸出入額」：UN, ECE (2004), No. 1, pp. 199-200（輸出は f.o.b. 輸 入は c.i.f.)。「GDP」 
の曲線の差は必ずしも貿易黒字（赤字）の大きさを示さないことに注意する必要がある。

これをみると，筆者の計算した「対ドル実質為替相場」でみても，IMFの「実質実効為替 相場」でみても，「実質為替相場」が 1996 年まで継続的に上昇していたこと，コリドールを年 間すべての期間で採用していた 1996 年と 1997 年の両年においては，それが高く安定していた こと, 1998 年のコリドール制崩壊をうけて相場が急落したこと, しかし，その後相場は持ち 直して, 2001 年ないし 2003 年には 1995 年の水準に近づいていることなどがわかる。では, 「実質為替相場」と財の輸入・輸出との関係はどらなっているのか見てみよう。

\section{（3）実質為替相場と財輸入・財輸出}

まず，財輸入は「実質為替相場」の動きと完全に即応している。「実質為替相場」の上昇は 輸入品の国内産品に対する割安, したがって輸入の増大をもたらし, 下落は輸入品の国内産品 に対する割高，したがって輸入の減少をもたらすのであるから，この結果は当然といえよう。 ただし，他国と比較するとこのことは必ずしも当然ではない。

実は, ハンガリーやポーランドでは，輸入額は「実質為替相場」にロシアほど敏感に反応し ていないのである。いわば，ロシアでは，輸入額の実質為替相場変動に対する弾力性が高い。 これは次のように考えると理解しやすい。すなわち，ロシアでは輸入はどのよらな品目であれ 「贅沢」であって，ある限界を超えて値が上がれば，買わないで「我慢」するだけであると。 この考穴は，「担ぎ屋」輸入の興隆と衰退という事態と結びっく。ロシアに打ける「担ぎ屋」 輸入の比重が大きく，「担ぎ屋」が「実質為替相場」に敏感に反応するからである。しかし， それですべてが説明できるかどらか。な拉，厳密な究明が必要である。

次に「実質為替相場」と輸出との関係をみよう。「理論的」には「実質為替相場」が上昇す れば輸出は減少し, 下落すれば輸出は増加するはずであるが, そのような動きを示した過渡期 国は多くない。ハンガリーやポーランドでは,「実質為替相場」が上昇傾向にあるときに輸出 は増加している。ここで注意する必要があるのは, ハンガリー・ポーランド両国では, 1992 年以降どの年も貿易収支は大幅な赤字であるという点である。したがって, 貿易收支の黒字が 「名目為替相場」を押し上げ，それが「実質為替相場」の上昇につながったのではない。

これに対してロシアでは, ハンガリーやポーランドに拈けると同じょらに，「理論」に反す る局面もないわけではないが，むしろ理論通りである年があって興味を引く。

1996 年から 1997 年にかけては, 「実質為替相場」が上昇しているなかで輸出は減少してい る（輸入は増加）。1998 年から 1999 年にかけては, 「実質為替相場」急落の下で輸出はごくわ ずかだが増加している (輸入は急減)。また，2000 年から 2001 年にかけては，「実質為替相場」 の上昇しているなかで輸出が減少している（輸入は増加）(10)。

しかし, この輸出の変動は, 「実質為替相場」の変動が作用したといらょりも, 石油価格変 動によるところが大きい。1996 年から 1997 年にかけて原油輸出価格が下落し, 原油輸出額も 减少していたのだが，1998 年から 1999 年にかけては原油輸出価格が急上昇している（1998 年 末以降は図 2)。さらに，2001 年にまた原油輸出価格が下落している(11)。これらの動きに従っ

(10)表 1 では「純輸出」は「財・サーヴィス」の「純輸出」だが，ここでは「財貿易」の「純輸出」である。 ただし，ロシアのサーヴィス貿易は常に赤字だから，表１の「純輸出」の貢献度の本質は「財貿易の 純輸出」である。な拉, ロシアではハンガリー, ポーランドとは異なって, 貿易収支は常に黒字で あった。

(11) 2002 年後半以降また原油輸出価格は上昇している。2002 年 7 月には 1 トン当たり 159.1 ドル, 


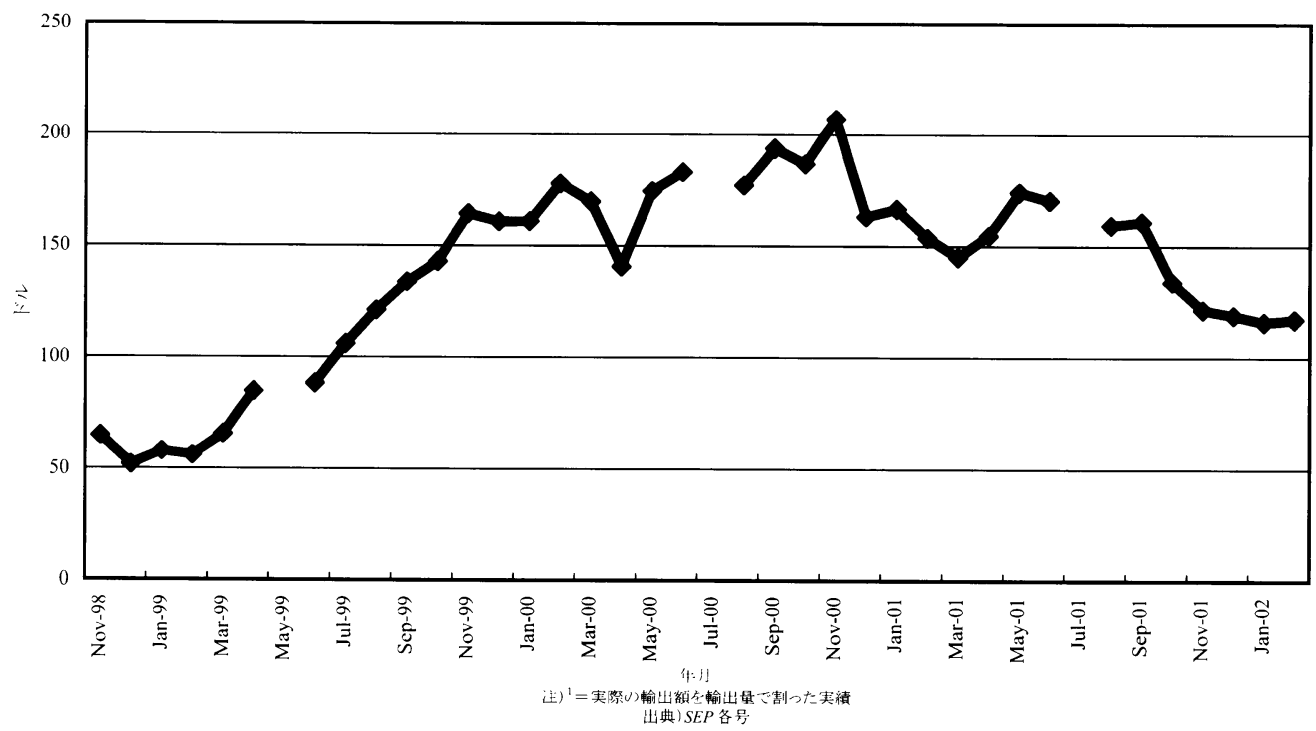

図 2 ロシア連邦の原油輸出価格（1トンあたり）1

て, 輸出額が増減したのである。2003 年の急成長も石油価格の上昇に起因するものである。 図 2 にみられるように石油輸出価格は 2002 年の前半期まで下落傾向を示していたのだが，そ の後再び上昇を続け，2003 年 12 月には 1 トン当たり 181.6 ドルとなった。この水準は 12 月の 水準としては 1998 年以来の最高値であった $(S E P \text { 各月号 })^{(12)}$ 。ロシアでは, 為替変動と原油 価格変動とが相まって, 輸出額が年によって大きく変動したのである。

このように，「実質為替相場」と輸出入との関係をみると，ハンガリ一経済やポーランド経 済と比較して，ロシア経済が，案外，対外経済関係のショックに傷つきやすい [vulnerable] 経済ではないかとの仮説が浮かび上がってくる。輸出の主要部分が，ぞこで生産されようと品 質に差はなく，国際的な投機の対象とされ，価格変動の激しい石油・ガスであること，軽工業 品輸入の多くが「担ぎ屋」によって担われてきたこと，機械輸入に関しては，対内直接投資が 本格化しておらず，長期的展望に立った着実な輸入がなされていないこと，これらの条件を考 慮すると，この vulnerability は納得のいくものである。この特質は，少なくとも移行期 10 年 の特質であったことは確かである。

\section{3 展望}

\section{（1）短期展望 $1 ：$ 石油価格}

危機後のロシアの経済成長は,「純輸出」の払大によって牽引されたものであり，「純輸出」 の拡大は，為替の下落と石油価格の上昇によってもたらされた。ここから，為替の上昇，石油 価格の下落が急速に進行すれば，「純輸出」は急减し，成長の動力が失われるだろら ${ }^{(13) ， と い ~}$

$\nearrow 2003$ 年 1 月には 183.8 ドルであった (SEP 各月号)。

(12) な拉, 天然ガスの輸出価格も激しく変動している。

(13) も5一つの懸念材料は, インフレーションの再熱である。不胎化政策を行えないとすると，外貨 ノ 
ら予想は容易である。ロシアの経済成長は脆弱な基盤の上に成り立っているのである。しか し，このことから，ロシアの成長がすぐにでも停止して2 度目の危機が来るとだろらといら予 想が出てくるわけではない。まず，短期的な観点から将来展望を試みてみよう。

ロシア経済の将来展望を行ならにあたって，第 1 にすべきことは，現在の石油価格の高騰が いつまで続くかを予想することであろう。このことは筆者の能力をはるかに超える課題である が，「現在の異常な石油高が，今後何年も続くとは考えられない」とまでは言ってもよかろう。 現在の石油高は，世界で矢継ぎ早に起こる事件に過剩に反応した心理的要因に後押しされたも のであると考学らるからである(14)。問題はそれがどの程度の水準に落ち着くかという点で ある。IFS の統計によれば, 2003 年の世界平均の原油価格は, 1 バレルあたり 28.9 ドルであっ た。2004〜 5 年の異常な心理的圧迫感が沈静化すれば, 少なくともこの程度までは下がる可 能性はある。他方, 1990 年代を通じた価格動向を見ると，1998年の 13.1 ドルが最低の水準 だった。今後数年間の間に, どのような情勢になろらとこれ以下には原油価格は下がらないと 考えても大過なかろう。以上から，仮に，原油価格を 1 バレルあたり 13.1 ドルと28.9ドルの 間で推移するものと考えてみよう (15)。

さて, 2003 年のロシア連邦の原油輸出量は 2 億 1300 万トン, 石油製品の輸出は 7750 万ト ンであった（RTs, 2004, pp. 409-410）。原油 2 億 1300 万トンは約 15 億 6600 万バレルである（1 トン=7.353 バレルとする)。したがって, 今後同程度の原油輸出が継続するとして，1 バレル 当たり 1 ドルの值下がりは，ロシア連邦にとって 15 億 6600 万ドルの輸出収入の減収となる。 また，石油製品に関して，石油製品の比重が原油と同じ，価格も原油と同じと仮定すれば，原 油の場合と同様の計算によって, 1 バレル当たり 1 ドルの值下がりが 5 億 6986 万ドルの減収 となる。両者を合計して，2003 年の原油ならびに石油製品の輸出量がそのまを確保されると して，世界市場の原油価格が 1 バレル当たり下落した場合，ロシア連邦にとって約 21 億ドル 余りの外貨減収となる(16)。

では, 原油価格が 1990 年代の最低水準 1 バレルあたり 13.1 ドルにまで下落したら，どうな るであろらか。上記の仮定から計算すると，337 億 4700 万ドルの減収となるわけだが(17)，そ れがロシア経済にとってどれほどの意味をもつ数字なのか。2003 年のロシア連邦の財（サー ヴィスを含まない) 輸出額は 1359 億 2900 万ドルであった。他の条件が全く变化しないとして, 世界市場の原油価格が 1 バレル当たり 13.1 ドルにまで下落した場合, 輸出額は 1000 億ドル前 後にまで下落することになる。しかし，この数字は，2000年の実績にはやや及ばないものの， 1999 年の輸出額実績よりはるかに大きなものである。近年では最高額となった 2003 年の商品 輸入実績（754 億 3600 万ドル）をそのまま当てはめても, 商品貿易において 270 億ドル程度

準備の増加は直接国内流通ルーブル通貨の増加をもたらし，それがインフレーションにつながるから である（Stoneman et al. 2000, p. 4）。

(14) 2003 年 5 月, ガイダルは, 異常な石油価格の高騰から得られた「配当」が戦争の終結と共に消えてな くなることは容易に理解できるとし，2004 年〜 5 年の経済政策においては過去 4 年よりずっと低い石 油価格が続くといらリスクを考慮すべきであると論じていた（Gaidar, 2003, p. 16）。実際には, 石油 高価格はガイダルの予想よりも持続しているよらである。

(15) ウラル原油の価格は, 2003 年に 27.2 ドル，1998年に 12.0 ドルだった（久保庭, 2004, p. 136）。こち らを参照価格として取れば，計算が若干異なってくる。

(16) 原油価格が上昇すればロシアにとってどの程度の増収をもたらすかといら観点から, 栖原（2004）が 同様の計算を行っている。

(17) $(15.66+5.6986) \times(28.9-13.1)=337.4659$ 
の黒字は確保できるはずである(18)。サーヴィス収支の赤字（2003 年に 110 億ドル程度）を考 慮しても，経常収支は黒字のままである。

経済成長の牽引車である経常収支の黒字（ほぼ「財・サーヴィスの純輸出」）が，原油価格 が現在の 3 分の 1 以下となっても, 維持されるであろらというこの結論は, ロシアにおける原 油生産力の向上によって導き出されたものである。ソ連崩壊後急速に落ち込んで 1996 年には 3 億 100 万トンにむで落ち込んだロシア連邦の原油生産は, 原油価格の上昇とともに回復し, さらに，新たな油田の開発も進んで 2002 年には 3 億 7960 万トンを記録し，2003 年には 4 億 2160 万トンに達した（小森，2004，p. 8) (19)。価格が仮に下落しても生産能力ひいては輸出能 力が増加しているため, 輸出額が確保される計算結果となるのである。

ただし，この推論には大きな欠陥がある。価格が下がっても，生産量は維持されると仮定し ているからである。現実には，ある水準を越えて価格が下がれば，採算割れとなって，生産を やめる油田が出てくるはずである。では，1 バレル何ドルの地点が， ロシア石油業にとっての 「損益分岐点」なのだろらか。もちろんこれを計算するには，ミクロおよびマクロの総合的な 判断が必要であって, 簡単に成しらることではない。しかし, 筆者は 1999 年以降のロシア原 油生産と原油世界市場価格との動向から，1 バレル 25 ドル上ならロシア連邦の原油増産は 続くと判断している(20)。そして, 現在の水準から 1 バレル 25 ドルの水準まで下落するには相 当の時間がかかるであろう。

確かにロシアの高成長は高い原油価格という脆弱な基盤の上に成り立っているものである が，4〜5年という短期的スパンで見た時，その基盤が崩壊してしまうとは考えられない。

\section{（2）短期展望 2 : 為替相場}

これまでのロシアの経済回復が低い為替相場によってもたらされた側面があるとするなら， 為替相場の上昇がロシア経済にマイナスに作用することは明らかである。そして実際図 1 に見 られるように実質為替相場は1999年以降上昇し, すでに 1995年の水準を越えている。これが, 輸出の減退, 輸入の増加, 国産品の輸入品による駆逐という事態につながるのであろうか。こ の問題も石油価格の問題と同様に二つの部分に分かれる。まず，為替相場そのものが今後どう 動くか，第 2 にその為替相場の動きがロシア経済にどう影響を与えるかである。

第 1 に問題に関していえば，理論的にいえば経常収支がプラスである限り，名目為替相場は 上昇し続けるといえる。そして実際上昇し続けるであろら ${ }^{(21)}$ 。しかし，このようなファンダ メンタルな動きは，国民経済の構造の漸進的な変化を伴いながらゆっくりと進行するのであっ て，このこと自体をロシア経済の短期的動向に対する不安材料とする必要はない。これはむし

(18) $1359.29-337.47-654.36=267.46$

(19) ただし，ソ連時代はソ連全体で 6 億トン程度算出していた。

(20) 1998 年から 1999 年にかけて, 原油価格がバレルあたり 13.1 ドルから 18.0 ドルに上昇した時, ロシア の原油生産は $0.6 \%$ しか増加しなかったのに, 2000 年に価格が 28.2 ドルとなると, 生産は $6.0 \%$ 増加

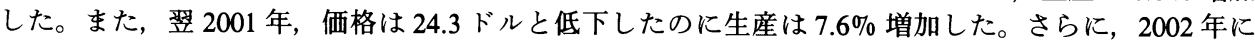
は価格が 25.0 ドルとやや持ち直し，生産は 9.2\% 増加した（栖原, 2004, p. 98）。なお，2004 年に創設 された「石油価格安定化基金」に拈いては，1 バレル 27 ドル（2005 年 4 月にこのように変更）を超 えた場合に，石油関連諸税の差額分を「基金」にプールする仕組みになっている。これも 1 つの基準 となろら。

(21) なお，1999 年，2000 年と国内物価水準が急上昇したため，2000年の実質実効為替相場は大きく上昇 した。物価の安定とともにこのような事態はあまり生じなくなるであろう。 
表 2 為替相場と輸出入（対前年比変化率：\%）

\begin{tabular}{|l|c|r|r|r|r|r|r|r|}
\hline & 1995 & \multicolumn{1}{|c|}{1996} & \multicolumn{1}{|c|}{1997} & \multicolumn{1}{c|}{1998} & \multicolumn{1}{c|}{1999} & \multicolumn{1}{c|}{2000} & \multicolumn{1}{c|}{2001} & \multicolumn{1}{c|}{2002} \\
\hline 対ドル実質為替相場 & 42.91 & 31.39 & 1.46 & -23.80 & -37.37 & 5.69 & 17.26 & 7.93 \\
\hline 財輸出額 & 21.56 & 9.93 & -4.09 & -14.33 & 1.49 & 39.02 & -3.25 & 5.20 \\
\hline 財輸入額 & 23.97 & 8.62 & 5.86 & -19.40 & -31.85 & 13.47 & 19.84 & 12.53 \\
\hline
\end{tabular}

出典) IFS 各所。

ろ次項で論じる中期的問題となろう。問題は何らかの外的ショックによって急激な為替変動が 生じるか否かである。これに関しては, どんな予想も成り立ちらるのであり, 明快な展望を描 くことは困難である。ただ，ここで注意する必要があるのは，ロシアでは，1998年の金融危 機に際して「コリドール制」が放棄され，現在厳密な意味での「固定制」は採用されていない とい5点である(22)。そのため，ブレトンウッズ体制が崩壊して固定制が崩壊し，急激な円高 に見舞われた 1970 年代初めの日本経済のような経験は，ロシアでは起こりえないのである。

第 2 の問題に関しては，表 2 の数字が参考になる。これをみると，財輸出額は必ずしも実質 為替相場の動向に左右されていない場合があるのに対して, 財輸入額は, 実質為替相場が上昇 すると増加するという関係があることがわかる。2000年以降に関していえば，実質為替相場 の上昇率より輸入額の増加率の汇らが大きい。いま，実質為替相場が，近年の最高值を記録し た 1997 年の水準をで上がるとするとそれは 2003 年の水準から約 $30 \%$ の上昇となる（図 1 参 照)。もしこれが 30\% 以上の財輸入の増加に帰結するとしてどうなるか。実はこれでも財貿易 の大幅黒字といら現在の姿にそれほどの変化はない。輸出額があまりにも大きいからである。 もちろん，財輸入の急激な増加は国際収支にだけ影響を及ぼすのではない。国内生産を駆逐し て，国内生産の低下をもたらすとともに，失業を招き国内消費水準を低下させるといら影響が 想定できる。30\% 以上の輸入増はこのよらな効果を及ぼすに充分な量ではある。しかし，輸 入額の増加がどのような商品の輸入によってもたらされるかも大きな問題である。「コリドー ル」期には, 担ぎ屋による軽工業品輸入が増大して, 彼らの持ち込んだ製品が国内を席巻し, それが国内軽工業の衰退を招いた。為替相場が上昇しても，それが，投資財輸入の増加に利用 されるようなら, 将来展望は異なったものとなろう。

\section{(3) 中期展望}

中期的な観点からいって現在のロシア経済の好調はどこまで持続するであろらか。ここでの 最も重要な論点は, 石油・ガスに依存したモノカルチャ一経済構造からの脱却がいかにして可 能かといらものである。この観点から我々が最も注視しなければならないのが，投資の動向で ある。

投資が 1999 年以降の経済回復過程で，大きな伸びを示していることはすでに述べた。しか し，ここでまず指摘しておかねばならないことは，投資の絶対水準がなお非常に低いといら点 である。1998 年までの投資の減退があまりに激しかったために, 最近の投資増加が目覚しく 見えるが，実は，2002 年の「基本資本投資」は1990年の水準の $40 \%$ にも満たない額なので

\footnotetext{
(22）ただし，通貨当局が適宜市場に介入していることも事実である。
} 
上垣彰

ある。さらに，資本減耗分を考虑するなら，資本投資額は見かけほど大きくないといら問題も 指摘されている。現在，ロシアでは機械・設備の老朽化が進んでいる（Lisin, 2004, p. 4, p. 12）。 旧政権の負の遺産とも称すべきこの問題は，若干の投資改善によっては解決できないほど重大 なものである。

次に, 今後, 投資が石油・ガス以外の分野に広がっていくかという問題がある。この点で も，悲観的な説が有力である。久保庭は，産業連関表を使った分析によって，石油・ガス部門 が，国内生産波及効果が小さい（ラスムッセンの影響力係数が小さい）のに，それが国内生産 の基幹セクターになっていることを指摘し，そこにロシアの「産業空洞化」の要因を見ている (久保庭, 1999, pp. 100-101) (23)。このことは, 結局, 石油・ガス部門の生産増加が石油・ガス 部門の投資増加だけにしか帰結せず，石油・ガス部門の生産増加 $\rightarrow$ 他部門の生産増加 $\rightarrow$ 他部門 の投資増加といら連関が生じないことを意味する。そもそもロシアに限らず，どの国でも天然 資源は経済発展にとってむしろ「呪い」であるとする説も存在するほどであり（栖原，2004， p. 101), この桎梏を打開して, 中長期的な発展につなげるためには, 意識的な政策誘導が必 要であろら(24)。

投資を石油・ガス以外の部門に回す際に重要な意味を持ってくるのが，金融システムであ る。ところがロシアではここに重大な問題がある。ロシアではデータの存在する 1994 年以降 ほぼ毎年，マクロ的には貯蓄過剩の状態にあった。この過剩な貯蓄の多くが海外に逃避してい ることは周知の事実である（Uegaki, 2004）。近年は，非合法的な逃避は減少したといわれてい るが，少なくとも合法的な資金の流出は止まっていない（経常収支が大幅黒字なのだから）。 ロシアの銀行は，オリガルヒの資金をインサイダー間で循環させ，また，海外で運用するため に使われる，オリガルヒの従属物である場合が多い。石油・ガス部門で作り出された資金を， 大衆の下に蓄積されている余唾資金とともに，広く集中して，それを将来有望な産業に自己の 責任のもとに投資していくょらな開かれた銀行は，ロシアにはまだ㕕っていない。ロシア企業 の投資資金源泉において，銀行借入の占める比率は 2001 年においても $3.5 \%$ に過ぎない（塩 原，2004，p. 196）。銀行危機が実体経済にそれほど影響を与えないという本稿冒頭で指摘し た金融システムの構造が将来に対する不安要因となっているのである。

もし，適切な政策が実施されずにモノカルチャー経済構造が温存されれば，何が生じるの か。20世紀の歴史を見る限り，このような国家では政治の腐敗と混乱が必然である。一種の レント争奪合戦が生じるからである。我々はこの点に重大な関心を持たざるを得ない。

石油価格の高騰と低為替によってもたらされたロシア経済の好調は, 短期的には挫折する可 能性は少ないといえる。しかし, 中期的な観点からいうと, ロシアのモノカルチャ一経済構造 からの脱却は，大きな困難を伴う。それは，将来に重大な問題を投げかけている。

(23) 久保庭はさらに進んで，石油・ガス産業の利益がロシアの統計では商業マージンとして登記されて扔 り，それが「資本逃避」のルートとなる可能性を指摘している（久保庭，2001）。田畑は久保庭の指 摘をらけて， ロシアの石油・ガス企業は，その組織構造をたくみに変更して，その利益を，配下の商 業・運輸部門に移転することによって，税支払を逃れていると論じた（Tabata, 2002, p. 622）。この「移 転」のメカニズム（「移転価格」）については塩原（2004, pp. 36-39）が詳しい。このロシア経済に関 する重大な発見は，世界銀行の最新のレポートでも利用されている。ただし，久保庭らの論文はなぜ か言及されていない（World Bank, 2004）。

(24) 電力，鉄道，住宅といった不採算部門の改革も大きな問題である（Iasin, 2003, pp. 13-15）。 
Bukaev, G. I., “Zadaniia po nalogam perevypolniaiutsia”, Finansy, No. 11, 2000.

Gaidar, E, "Vosstanovitel'nyi rost i nekotorye osobennosti sovremennoi ekonomicheskoi situatsii v Rossii", Voprosy ekonomiki, No. 5, 2003.

Iasin, E., "Strukturnyi manevr i ekonomicheskii rost", Voprosy ekonomiki, No. 8, 2003.

IFS [International Monetary Fond, International Financial Statistics], Washington, DC.

小森吾一『ロシアの石油・天然ガス』(東洋書店), 2003。

Kuboniwa, Masaaki, “An Analysis of Singularities of Russia's Marketization using Input-Output Tables”, The Journal of Econometric Study of Northeast Asia, Vol. 4, No. 1, 2002.

Lisin, V., "Investitsionnye protsessy v Rossiiskoi ekonomike", Voprosy ekonomiki, No. 6, 2004.

Lisin, V. and S. Seregina, "Eshcho raz o kharaktere i urokakh postdefoltnoi makroekonomicheskoi dinamiki", Rossiiskii ekonomicheskii zhurnal, No. 1, 2004.

RET [Russian Economic Trends].

$R T$ s [Rossiia $v$ tsifrakh].

SEP [Sotsial'no ekonomicheskoe polozhenie].

Stoneman, Richard, Peter Oppenheimer and Patricia Isaeva, "Russia - A Growing Economy in the New Millennium?", RET, 11 Oct. 2000.

Tabata, Shinichiro, "Russian Revenues from Oil and Gas Exports: Flow and Taxation," Eurasian Geography and Economics, Vol. 43, No. 8, 2002.

Uegaki, Akira, "Russia as a Newcomer to the International Financial Market, 1992-2000", Acta Slavica Iaponica, Tomus XXI, 2004.

Uegaki, Akira, "Russia and the IMF", TABATA Shinichiro and IWASHITA Akihiro (eds.), Slavic Eurasia's Integration into the World Economy and Community, Slavic Research Center, Hokkaido Univ., 2004.

UN, ECE [United Nations, Economic Commission for Europe], Economic Survey of Europe, No. 1, 2004, Geneva.

World Bank, Russian Economic Report, Feb. 2004.

朽木 昭・野上裕生・山形辰史『テキストブック開発経済学（新版）』(有斐閣)，2004。

久保庭真彰「産業構造の変動」, 久保庭真彰, 田畑伸一郎（編著）『転換期のロシア経済』（青木書店）, 1999。

久保庭真彰「ロシア市場経済化の特殊性一一商業マージンの分析を中心として一」, 『経済研究』(一橋 大学経済研究所), No. 52, No. 2, Apr. 2001。

久保庭真彰「ロシア経済成長の新たな波と産業構造」,『経済研究』(一橋大学経済研究所), Vol. 55, No. 2, Apr. 2004。

塩原俊彦（2004）『現代ロシアの経済構造』（慶應義塾大学出版会），2004。

栖原 学「ロシア経済と天然資源」,『経済研究』(一橋大学経済研究所), Vol. 55, No. 2, Apr. 2004。 